\title{
ASOSIASI PORNOGRAFIS DALAM BAHASA SMS
}

\author{
oleh Teguh Santoso \\ Balai Bahasa Banda Aceh
}

\begin{abstract}
There are two principal approaches to semantic studies. The one focuses on the referent and the other upon the conceptual constructs. The first is largely extensional, the second primaly intensional.

This article content the semantics analysis upon the conceptual constructs. There is some data on cellular that's name short message service. One of the fitur on the cellular always used by one's to make a joke. Commonly, the joke about pornography. Of course, the language as medium is very rich of sensation likes association. So, this article try to find why this happened and what is the factor of the porno context to raise.
\end{abstract}

Keywords: referent, conceptual constructs, association, context

\section{A.Pendahuluan}

Bahasa adalah sistem lambang bunyi yang arbitrer yang digunakan oleh para anggota kelompok sosial untuk bekerja sama., berkomunikasi, dan mengidentifikasikan diri (Kridalaksana via Chaer, 1994:32). Oleh karena itu, bahasa merupakan salah satu sarana bagi manusia untuk memudahkannya bersosialisasi dengan manusia lain. Melalui bahasa, manusia dapat berkomunikasi dengan sesamanya sehingga terbentuk suatu interaksi sosial.

Sebagai alat komunikasi, bahasa terdiri atas dua bagian, yaitu bentuk (lambang) yang berupa ujaran-ujaran dan makna (isi). Makna adalah isi yang terkandung di dalam bentuk atau lambang itu. Makna merupakan hubungan antara bahasa dan dunia luar yang telah disepakati bersama oleh para pemakai bahasa sehingga dapat saling dimengerti (Aminuddin, 1988:53). Dalam bukunya berjudul Diksi dan Gaya 
Bahasa (1991:25), Keraf mengemukakan bahwa kata sebagai satuan dari perbendaharaan kata sebuah bahasa mengandung dua aspek, yaitu aspek bentuk atau ekspresi dan aspek isi atau makna. Bentuk adalah aspek yang dapat diserap dengan pancaindera, yaitu dengan mendengar atau dengan melihat. Sebaliknya, aspek isi adalah aspek yang menimbulkan reaksi dalam pikiran pendengar atau pembaca karena rangsangan aspek bentuk tersebut.

Asosiasi pornografis dalam bahasa yang digunakan dalam alat komunikasi handphone berupa layanan short message service (SMS) memanfaatkan relasi bentuk yang dapat menimbulkan reaksi berbeda dalam pikiran pembaca atau pendengar. Hal tersebut terbukti dengan banyaknya penggunaan kata-kata yang berpotensi untuk menimbulkan asosiasi pornografis dalam penelitian ini. Saat ini perkembangan teknologi seluler membawa dampak pada penggunaan bahasa melalui layanan SMS tersebut. Salah satu bahasa dalam SMS yang sering dijumpai yaitu pemakaian bahasa dengan penyimpangan makna dengan tujuan humor. Tujuan ini lebih spesifik bersifat hiburan. Oleh karena itu, muncul berbagai kreativitas dalam menulis SMS. Media yang digunakan berupa handphone menjadi pilihan seseorang berkreativitas bahasa karena faktor privat atau personal. Seperti diketahui, seorang pengguna handphone tidak akan takut atau kawatir apabila pesan SMS diketahui oleh orang lain.

Selanjutnya, Wijana (2003:3) dalam makalah berjudul "Pornografi dan Asosiasi Pornografis pada Judul Rubrik Artis Harian Bernas Yogyakarta" mengemukakan batasan antara pornografi dan asosiasi pornografis. Pornografi adalah perbincangan masalah seksual atau segala sesuatu yang berkaitan dengan aktivitas seksual secara terus terang. Jadi, bentuk lingual (kata, frase, atau konstruksi lingual) dipergunakan secara langsung untuk mengacu ke arah aktivitas seksual atau hal-hal yang berkaitan dengan aktivitas itu. Asosiasi pornografis adalah bentuk-bentuk lingual yang memiliki kemampuan untuk diasosiasikan dengan hal-hal yang berbau seksual oleh para pembaca, 
tetapi dimaksudkan lain oleh para penulis SMS.

Kemampuan asosiasi bentuk-bentuk lingual itu dimanfaatkan untuk mengecoh pikiran pembaca sehingga menciptakan semacam daya tarik untuk membacanya secara keseluruhan. Penggunaan kata-kata yang memiliki asosiasi pornografis ini menjadi menarik karena menimbulkan rasa keingintahuan pembaca dan memberikan sedikit hiburan. Selain itu, penggunaan kata-kata yang memiliki asosiasi pornografis ini juga merupakan sarana yang ampuh untuk menjembatani komunikasi.

Penggunaan kata-kata yang memiliki asosiasi pornografis sebenarnya merupakan hal yang normal dan lazim digunakan dalam praktik berbahasa. Oleh karena itu, hal tersebut patut dikaji secara linguistik sebagai suatu fenomena kebahasaan yang berkembang dalam masyarakat.

Belum adanya penelitian yang mendalam mengenai asosiasi pornografis dalam bahasa SMS mendorong peneliti untuk melaksanakan penelitian ini mengingat pornografi tersebut erat kaitannya dengan penyimpangan makna primer ke makna sekunder. Berdasarkan hal tersebut, masalah yang akan dibahas dalam penelitian ini sebagai berikut.

a. Aspek-aspek kebahasaan apa sajakah yang dimanfaatkan untuk membentuk asosiasi pornografis?

b. Apakah fungsi pornografis dan asosiasi pornografis dalam bahasa SMS?

\section{B. Tujuan Penelitian}

Penelitian ini bertujuan untuk mendapatkan gambaran mengenai aspek-aspek kebahasaan dan cara-cara yang digunakan oleh penulis SMS untuk menciptakan asosiasi pornografis. Hasil dari penelitian ini diharapkan dapat membuktikan dan menjelaskan adanya aspek-aspek kebahasaan yang digunakan dalam bahasa SMS dan cara-cara yang ditempuh oleh penulis SMS untuk menciptakan asosiasi pornografis 
sebagai sebuah fenomena kebahasaan yang layak mendapat perhatian.

\section{C.Landasan Teori}

Penelitian mengenai asosiasi pornografis dalam bahasa SMS ini menggunakan beberapa teori yang mendukung pelaksanaan penelitian. Sebagai landasan penelitian digunakan pendekatan semantis. Semantik adalah bidang studi dalam linguistik yang mempelajari makna atau arti bahasa. Semantik adalah ilmu tentang makna atau tentang arti (Chaer,1990:2). Pendapat yang sama dikemukakan oleh Verhaar yang menyebut semantik sebagai teori makna atau teori arti (1987:124).

Semantik merupakan bidang yang sangat luas. Di dalamnya terlibatkan unsur-unsur struktur dan fungsi bahasa, yang berkaitan erat dengan psikologi, filsafat, dan antropologi, serta sosiologi (Lehrer via Djajasudarma, 1993:3). Menurut Djajasudarma (1993:2) semantik merupakan bagian dari tiga tataran bahasa yang meliputi fonologi, tata bahasa (morfologi, sintaksis), dan semantik.

Semantik ini mengasumsikan bahwa bahasa terdiri atas struktur yang menampakkan makna dihubungkan dengan objek lain di dunia. Pendapat yang sama juga dikemukakan oleh Wijana (1999:10) bahwa dalam ilmu makna (semantik) satuan-satuan kebahasaan memiliki hubungan bentuk dan makna dengan satuan kebahasaan yang lain. Selain itu, satuan-satuan kebahasaan dapat memiliki berbagai makna.

Pengertian kata "makna" (sense) dibedakan dari kata arti (meaning) di dalam lingkup kajian semantik. Makna merupakan pertautan yang ada di antara unsur-unsur bahasa itu sendiri (terutama kata-kata). Makna menurut Palmer (via Djajasudarma,1993:5), hanya menyangkut intrabahasa. Sesuai dengan pendapat tersebut, Lyons menyebutkan bahwa mengkaji atau memberikan makna suatu kata adalah memahami kajian kata tersebut yang berkenaan dengan hubungan-hubungan makna yang membuat kata tersebut berbeda dengan kata-kata lain.

Makna ini oleh Wijana (1999:7) kemudian digolongkan menjadi 
makna leksikal dan makna gramatikal, makna denotatif dan makna konotatif, makna literal dan makna figuratif, serta makna primer dan makna sekunder. Masalah pornografi yang dibahas dalam penelitian ini sendiri erat kaitannya dengan makna primer dan makna sekunder. Hal ini dimungkinkan karena kata-kata yang digunakan berpotensi menimbulkan asosiasi pornografis pada pembaca.

\section{Metode Penelitian}

Metode penelitian yang digunakan dalam penelitian ini meliputi beberapa tahapan strategis yaitu metode pengumpulan data, analisis data, dan penyajian hasil analisis data (Sudaryanto, 1988:57).

Tahapan pertama, pengumpulan data dilakukan dengan metode simak. Teknik lanjutannya adalah teknik simak bebas libat cakap (SBLC) dan teknik catat. Data diperoleh dari pemegang handphone di lingkungan sekitar penulis, baik di kampus, rumah, maupun kantor. Data tersebut kemudian penulis lengkapi dari data sekunder berupa bukubuku kumpulan humor SMS yang banyak beredar di masyarakat. Data ini sebagian besar berkaitan dengan kalangan muda (pelajar, mahasiswa) sebagai pemakai handphone. Pada umumnya SMS ini dikirim oleh seseorang kepada orang lain. Pengirim SMS tentu saja telah mengetahui siapa dan bagaimana si penerima SMS. Oleh karena itu, tidak pernah ditemukan persoalan yang ditimbulkan oleh pengiriman SMS ini. Justru pengiriman SMS ini memancing si penerima SMS untuk membalas kembali (reply) dengan SMS yang lebih kreatif dan bahkan lebih "porno".

Data yang diperoleh tersebut kemudian diklasifikasikan dan selanjutnya dianalisis. Analisis data dilakukan dengan metode kontekstual yang memperhatikan makna kata, kalimat, dan klausa berdasarkan konteksnya, baik yang bersifat lingual maupun situasional, sehingga penyimpangan aspek-aspek kebahasaannya dapat diidentifikasikan. Dengan analisis tersebut, arti umum dan arti khusus dapat diketahui karena di dalam konteks tersembunyi ciri pembeda dari 
suatu butir kebahasaan.

Langkah terakhir adalah penyajian hasil analisis data. Penyajian hasil analisis data dilaksanakan secara deskriptif.

\section{E. Referensi Pornografis}

Kata "pornografi" menurut Webster's New Word Dictionaryi (via Lesmana, 1995:69) berasal dari bahasa Yunani yang terdiri atas dua suku. kata, porne dan graphein. Porne dapat diartikan sebagai 'pelacuran' dan graphein sebagai 'tulisan atau gambar'. Dalam Kamus Besar Bahasa Indonesia (2001:696), pornografi diartikan sebagai 'penggambaran tingkah laku secara erotis dengan lukisan atau tulisan untuk membangkitkan nafsu birahi'. Pengertian pornografi ini kemudian berkembang dan menjadi sebuah perdebatan di antara para ahli.

Menurut HB. Yassin (via Lesmana, 1995:109), pornografi adalah setiap tulisan atau gambar dengan maksud sengaja untuk merangsang seksual. Sifat dari pornografi ini membuat fantasi pembaca menjadi bersayap dan melayang ke daerah-daerah alat kelamin dan menyebabkan syahwat berkobar-kobar. Oleh karena itu, Arief Budiman (via Lesmana, 1995:76) membedakan pornografi dengan penghayatan erotis. Penghayatan erotis timbul dalam diri seseorang ketika dirangsang oleh hal-hal yang menimbulkan pikiran-pikiran atau perasaan-perasaan yang ada hubungannya dengan aktivitas seksual. Dengan demikian, sesuatu yang porno belum tentu menimbulkan penghayatan erotis dan sebaliknya, sesuatu yang menimbulkan penghayatan erotis belum tentu porno.

Secara umum, tulisan, gambar, foto, dan tontonan dianggap porno jika memenuhi unsur-unsur sebagai berikut. (1) Kesengajaan untuk membangkitkan nafsu birahi orang lain. (2) Maksud atau tujuan untuk merangsang nafsu birahi. Artinya, sejak semula memang sudah direncanakan atau telah ada dalam benak si pembuat untuk merangsang birahi khalayak atau setidak-tidaknya mengetahui apabila hasil karyanya dapat menimbulkan rangsangan birahi di pihak lain. (3) Karya 
tersebut tidak mempunyai nilai (merit) lain kecuali sebagai sexual stimulant semata-mata. (4) Menurut standar moral kontemporer yang dianut masyarakat setempat, tidak pantas diperlihatkan atau diperagakan secara umum. Asosiasi pornografis adalah bentuk-bentuk lingual yang memiliki kemampuan untuk diasosiasikan dengan hal-hal yang berbau seksual oleh para pembaca, tetapi dimaksudkan lain oleh para penulis (Wijana, 2003:3).

Tidak semua tulisan yang menggunakan kata atau frase yang berhubungan dengan organ seksual termasuk pornografi walaupun tulisan tersebut membuat para pembaca berpikiran ke hal-hal yang berbau porno. Hal ini merujuk pendapat HB. Yassin (via Lesmana, 1995:75) bahwa untuk menilai suatu karya tulisan atau gambar termasuk porno atau tidak harus dilihat secara keseluruhan dan didukung oleh ide yang baik atau tidak. Apabila kata atau frase tersebut digunakan dalam bidang tertentu, misalnya kedokteran, tentu penggunaan kata atau frase yang memuat organ seksual tidak akan meimbulkan asosiasi pornografis pembacanya. Oleh karena itu, faktor konteks dan ide sangat penting diperhatikan dalam upaya mencari makna asosiasi pornografis.

Kata-kata yang berpotensi menimbulkan asosiasi pornografis ini dapat digolongkan sesuai dengan referen atau acuannya, yaitu (1) alat kelamin,(2) kekuatan, (3) aktivitas seksual.

\section{F. Asosiasi Pornografis pada Bahasa SMS}

Menurut Wijana (1999:7) secara umum jenis makna dibagi menjadi dua kelompok makna, yaitu makna yang dapat diidentifikasi tanpa bantuan konteks atau makna primer dan makna yang hanya dapat diidentifikasikan dengan bantuan konteks atau makna sekunder. Makna primer ini meliputi makna leksikal, denotatif, dan literal. Makna sekunder meliputi makna gramatikal, konotatif, dan figuratif. Makna sekunder inilah yang mengakibatkan makna asosiasi pornografis seperti dimaksudkan pada penelitian ini.

Menurut Wijana (1999:9), makna sekunder adalah makna satuan 
kebahasaan yang hanya dapat diidentifikasikan melalui konteks pemakaian bahasa. Contoh data (1) berikut.

Istri yang sopan kalo minta duit: burung pipit makan kedondong, minta duit dong!

Suami menjawab: burung pipit makan kedondong, burungku dijepit duludong!

Pada data (1) di atas, terdapat makna sekunder pada kata "burung" dan kata "dijepit". Makna denotatif kata "burung" yaitu 'salah satu jenis unggas yang dapat terbang', sedangkan kata "dijepit" memiliki makna denotatif 'ditekan dengan dua sisi'. Kedua kata tersebut menimbulkan asosiasi pornografis karena telah terjadi perubahan makna primer menjadi makna sekunder. Makna sekunder tersebut dapat diketahui apabila konteks dalam bahasa SMS tersebut diperikan. Tuturan dalam contoh data (1) di atas terjadi pada situasi keluarga karena ada kata "suami" dan kata "istri". Makna sekunder yang ditimbulkan oleh konteks tersebut bahwa kata "burung" mengacu pada 'alat kelamin pria' dan kata "dijepit" mengacu pada 'aktivitas hubungan seksual'.

Sebuah kata disebut mempunyai makna konotatif apabila kata itu mempunyai "nilai rasa", baik positif, maupun negatif (Chaer, 1990:65). Sesuai dengan pendapat tersebut Djajasudarma (1993:9) mengemukakan bahwa makna konotatif muncul sebagai akibat asosiasi perasaan kita terhadap apa yang diucapkan atau apa yang didengar.

Menurut Kridalaksana dalam Pateda (1986:62) makna konotatif adalah aspek makna sebuah atau sekelompok kata yang didasarkan atas perasaan atau pikiran yang timbul atau ditimbulkan pada pembicara (penulis) dan pendengar (pembaca). Dengan kata lain, makna konotatif merupakan makna leksikal $+X$. $X$ tersebut mengacu pada leksem yang maknanya ditentukan oleh konteks, sehingga memiliki nilai rasa.

Makna konotatif bukan makna sebenarnya. Makna ini tidak seperti adanya, tetapi mengandung makna lain yang kadang-kadang masih berhubungan dengan sifat, rasa benda, atau peristiwa yang 
dimaksudkan. Makna konotatif, berbeda dengan makna denotatif karena sifatnya tidak stabil, sesuai dengan intensitas rasa yang dimiliki dan tidak terbatas. Jadi, makna konotatif ini erat hubungannya dengan nilai rasa seorang penutur bahasa. Berikut data (2) yang menunjukkan hal tersebut.

Cowok yang telah menikah akan lebih gemuk daripada cewek. Karena mendapat 2 susu, 2 paha, dan 1 apem. Sementara cewek hanya dapet 2 telor dan 1 pisang.

Pada contoh (2) selain konteks yang telah dirujuk terlihat pada kata "cowok" dan kata "cewek", juga terdapat makna konotatif pada kata "susu", "paha", "apem", "telor" dan "pisang". Keta-kata tersebut menimbulkan asosiasi pornografis karena terikat konteks pada kedua kata seperti disebutkan yaitu "cowok" dan "cewek". Asosiasi pornografis ini muncul karena terjadi perubahan makna konotatif. Makna konotatif pada kata-kata tersebut memiliki nilai rasa yang berbeda. Akan tetapi, secara umum makna konotatif yang timbul pada contoh (2) bersifat negatif. Munculnya konotatif negatif ini karena nilai rasa yang ditimbulkan sangat jauh dari makna kata tersebut sebenarnya (denotatif). Kata-kata bermakna konotatif semuanya mengacu pada bagian tubuh manusia. Kata "susu" mengacu pada organ vital wanita yang lebih dikenal dengan 'payudara'. Kata "paha" juga demikian halnya. Kemudian kata "apem" mengacu pada 'alat kelamin wanita". Kata "apem" ini memiliki makna denotatif 'kue tradisional, bentuk bulat, empuk, gurih'. Kata "telor" mengacu pada 'buah pelir'. Kata tersebut direpresentasikan dengan makna konotatif tersebut karena memiliki kesamaan bentuk bulat. Kata "pisang" juga mengacu pada 'alat kelamin pria/ penis' karena persamaan bentuknya yang panjang dan bulat. Dalam contoh (2) muncul asosiasi pornografis melalui makna konotatif yang memiliki nilai rasa negatif. Nilai rasa negatif tersebut lebih banyak mempengaruhi dalam penafsiran makna dalam konteks bahasa SMS contoh (2) secara keseluruhan. 
Data (3)

UNDERSTAND artinya mengerti

UNDER artinya di bawah

STAND artinya berdiri

Jadi kalo di bawah udah berdiri, maka kamu pasti sudah mengerti.

Data (3) pada awalnya memiliki makna denotatif. Makna tersebut merupakan makna sebenarnya dari padanan bahasa asing (bahasa Inggris) ke dalam bahasa Indonesia. Kata dalam bahasa Inggris tersebut masing-masing kemudian dipisah sehingga diperoleh kata "under" dan kata "stand". Arti kedua kata tersebut kemudian dirangkaian dengan arti kata pertama "understand" sehingga diperoleh kalimat bahasa Indonesia seperti dalam data (3) baris terakhir.

Penyimpangan yang dapat ditemukan terdapat pada arti kata "understand" dalam bahasa Indonesia dengan "mengerti" dalam bahasa Indonesia. Kata tersebut digunakan untuk menunjukkan hal yang sama pada kata "under" yang berarti 'di bawah' dan kata "stand" yang berarti 'berdiri'. Asosiasi pornografis yang dapat dikemukakan merujuk pada alat kelamin pria. Hal ini dapat dijelaskan berdasarkan perian kata "understand" yang disimpangkan menjadi frase dalam bahasa Indonesia "di bawah berdiri". Oleh karena itu, sesuatu di bawah yang dapat berdiri merujuk pada organ pria tersebut.

Makna figuratif adalah makna sebuah bentuk kebahasaan yang menyimpang dari referennya (Wijana, 1999:9). Kridalaksana dalam Pateda (1986:59) mengemukakan makna figuratif sebagai pemakaian leksem dengan makna yang tidak sebenarnya. Contoh data (4) berikut.

Wanita sering tidak konsisten

Sering demo, teriak-teriak anti kekerasan

Pas ada maunya malah minta yang KERAS

Pada data (4) dapat ditemukan dua buah kata yang memiliki referen yang sama yaitu kata "kekerasan" dan kata "keras". Kedua kata 
merujuk pada sebuah sifat sebuah benda atau hal. Akan tetapi, asosiasi pornografis muncul pada saat kata "keras" merujuk pada frase "ada maunya". Dengan demikian, pemakaian kata "keras" digunakan dengan makna yang tidak sebenarnya. Makna yang dimaksudkan dalam asosiasi pornografis adalah 'organ pria sedang ereksi'.

Penyimpangan makna yang terjadi pada bahasa SMS merupakan sesuatu yang biasa dilakukan, dalam arti tidak melanggar atau menyalahi kaidah yang berlaku. Penyimpangan tersebut ditujukan kepada penerima atau pembaca sebagai hiburan atau humor. Penyimpangan makna tersebut terjadi karena adanya pilihan kata yang bermakna primer yang selanjutnya disimpangkan menjadi bermakna sekunder. Data (5) berikut menunjukkan gejala demikian.

Pakian apakah yang ukurannya paling besar?

Daster wanita, karena di balikdaster wanita, Ada 2 pabriksusu, 1 pabrikpupuk,

1 pabrikgas, dan 1 tempat hiburan, yang paling dinikmati di dunia.

Data (5) menunjukkan terjadinya penyimpangan makna pada gabungan kata "pabrik susu", "pabrik amonia", "pabrik gas", dan klausa "tempat hiburan paling dinikmati di dunia". Penyimpangan tersebut dituntun oleh kata "pakaian" pada kalimat pertama. Dengan demikian, dapat diketahui bahwa salah satu fungsi pakaian adalah menutup anggota tubuh. Berdasarkan hal tersebut, penyimpangan makna pada frase atau gabungan kata tersebut di atas mengacu pada hal-hal fisik dan anggota tubuh. Dalam hal ini anggota tubuh perempuan, yang ditandai oleh penggunaan kata "daster". "Daster" merupakan pakaian yang digunakan oleh wanita dengan ukuran relatif longgar. Oleh sebab itu, kelonggaran tersebut disimpangkan dengan kemampuan menutupi bagian-bagian tubuh yang juga disimpangkan dengan frase-frase 
tersebut di atas.

Frase "pabrik susu" mengacu pada makna 'fungsi payudara yang menghasilkan ASI (Air Susu Ibu)'. Frase "pabrik pupuk" mengacu pada anus yang berfungsi sebagai pembuang kotoran (veses)'. Frase "pabrik gas" memiliki acuan yang sama dengan "pabrik pupuk" hanya saja yang dikeluarkan bukan kotoran (veses), tetapi yang umum dikenal sebagai kentut, sedangkan klausa "tempat hiburan yang paling dinikmati di dunia" mengacu pada 'organ kewanitaan'. Asosiasi pornografis terdapat pada semua frase dan klausa tersebut karena salah satu penyimpangan makna yang menimbulkan asosiasi pornografis, salah satunya mengacu pada 'alat kelamin dan daerah sekitarnya'. Dengan demikian, penggunaan frase-frase "pabrik pupuk" dan "pabrik gas" sesuai dengan pendapat tersebut karena letak kedua acuan dalam kedua frase tidak berada jauh dari makna konotatif yang terkandung dalam klausa bahasa SMS data (5) tersebut.

Penyimpangan makna tersebut timbul karena adanya asosiasi dari pembaca. Asosiasi yang muncul tersebut yang kemudian mengacu ke arah pornografi. Menurut Wijana (1999:15) asosiasi pornografis adalah bentuk-bentuk lingual yang memiliki kemampuan untuk diasosiasikan dengan hal-hal yang berbau seksual oleh para pembaca, tetapi dimaksudkan lain oleh para penulis yang bersangkutan.

Data yang mengalami penyimpangan makna primer menjadi makna sekunder berturut-turut sebagai berikut.

Data (6)

Ehloe taunggak

Wanita itu lebih kuat dari laki-laki,

Buktinya, wanita bisa mengangkat 2 buah gunung

Kemana-mana dengan tegak,

Laki-laki bawa 2 telur kecil aja,

Dibantuama burung.

Data (6) di atas menunjukkan penyimpangan makna primer 
menjadi sekunder. Penyimpangan terjadi pada kata "kuat" yang mengacu pada makna 'kemampuan mengangkat atau membawa'. Dalam konteks bahasa SMS data (6) acuan tersebut tampak pada penggunaan kata "mengangkat". Pengertian "kuat" tersebut disimpangkan dengan kata-kata selanjutnya. Kata-kata tersebut adalah "gunung", telur", dan "burung'. Dalam hal ini ketiga kata tersebut memiliki rujukan makna yang bersifat sekunder. Oleh karena itu, ketiga kata tersebut mengacu pada hal-hal yang menimbulkan asosiasi pornografis. Kata "gunung" mengacu pada makna 'payudara' dengan menggunakan persamaan bentuk antara gunung dan payudara. Kata "telur" memiliki acuan pada makna 'buah pelir'. Hal ini juga dilakukan penulis SMS melalui persamaan bentuk yaitu 'bulat'. Telur merepresentasikan 'buah pelir' karena persamaan bentuk tersebut. Kemudian kata "burung" mengacu pada makna 'alat kelamin pria'. Model acuan yang digunakan tidak sama seperti dua kata di atas. Penggunaan kata "burung" dalam asosiasi pornografis selalu mengacu pada organ vital laki-laki. Hal ini lebih banyak disebabkan oleh faktor kultural. Seperti diketahui bahwa dalam masyarakat tradisional masih mengenal kata-kata yang dianggap tabu. Oleh karena itu, mereka kemudian membuat sebutan bagi hal-hal yang dianggap tabu. Seperti halnya kata "burung" ini. Namun, secara pasti tidak dapat diketahui relevansi antara "burung" dengan "organ vital lakilaki”.

Data (7)

Seorang pembantu sedang membujuk anak laki-laki majikannya untukmakan

Ayo makan, dagingnya enak, setelah itu nanti minum susunya.

Enggak, enggak, saya kan enggak suka daging dan susu, kata si anak

Awas nanti kalau sudah besar, kata si pembantu

Tuh liat bapakmu, enggak boleh liat daging sama susu, langsung saja.

DIKSI Vol.11, No.2, Juli 2004 
Data (7) juga mengalami proses penyimpangan makna yang berasal dari makna denotatif menjadi makna konotatif. Seperti telah disebutkan di atas bahwa penyimpangan makna tidak dapat dilepaskan dari konteks pemakaian kata tersebut dalam sebuah kalimat maupun wacana. Data (7) merupakan wacana yang memiliki konteks sosial berupa seorang pembantu dengan anak laki-laki sang majikan. Berdasarkan konteks tersebut saja dapat ditebak hubungan status antara pembantu dan majikan. Pembantu rumah tangga selalu berada pada posisi yang terpinggirkan daripada si majikan. Hal itulah yang kemudian tampak dalam bahasa SMS di atas. Penyimpangan makna terjadi pada kata "daging" dan "susu". Kata "daging" yang merupakạn makna denotatif 'lauk makanan' pada konteks wacana data (7) berbeda dengan kata "daging" pada kalimat baris terakbir SMS di atas. "Daging" yang dimaksudkan tentu saja mengacu pada makna 'organ vital perempuan'. Demikian halnya dengan kata "susu", memiliki dua makna pada konteks wacana data (7). Pertama, bermakna 'minuman'. Kedua, bermakna 'payudara' atau 'susu dalam arti bagian fisik perempuan'.

Kedua makna konotatif tersebut menimbulkan asosiasi pornografis ketika pada kalimat terakhir terdapat kata ganti persona "bapakmu" yang diteruskan dengan frase "enggak boleh liat". Hal ini menyiratkan maksud bahwa sang majikan (bapak dari si anak laki-laki) memiliki kesenangan menggoda pembantunya. Hal tersebut justru tidak menjadi masalah bagi si pembantu yang ditandai oleh frase "langsung saja". Berdasarkan analisis tersebut dapat ditarik simpulan bahwa asosiasi pornografis pada wacana SMS data (7) mengacul pada 'alat kelamin atau organ tubuh' dan 'aktivitas seksual' antara pembantu dan majikan.

Data (8).

Apa beda kucing dengan cowok, Kalo kucing dielus-elus tidur, Kalo cowok dielus-elus bangun. Apa beda daun pepaya dan tangan cewek 


\section{Kalo daun pepaya bisa bikin daging jadi lembek, Kalo tangan cewek bisa bikin daging menjadi keras.}

Data (8) asosiasi pornografis terjadi pada penyimpangan makna pada kata "cowok" dan kata "daging". Kedua kata tersebut dalam konteks data (8) menunjukkan komparasi aktivitas. Asosiasi kata "cowok" diidentikan dengan benda atau sesuatu yang dapat bangun. Padahal sesuatu atau benda yang dimaksud bisa apa saja yang ada dalam fisik laki-laki-cowok. Namun demikian, apa yang dimaksudkan dengan kata "bangun" terhadap kata "cowok" merujuk pada 'organ vital lakilaki'. Perbandingan dalam data (8) dilakukan untuk mencapai efek pornografis dalam benak pembaca SMS. Pebanding dalam data (8) berupa kata "kucing", sedangkan pembandingnya adalah kata "cowok".

Hal yang sama juga terjadi pada frase "daun pepaya" sebagai pebanding dan frase "tangan cewek" sebagai pembanding. Asosiasi pornografis dilakukan dengan melalui kontrastif kata "keras" dengan kata "lembek". Kontras yang dilakukan oleh penulis SMS yakni terhadap kata "daging". Kata "daging" pada data (8) tersebut memiliki dua makna yang berbeda. Yang pertama makna denotatif sebagai 'daging yang secara harfiah dapat dimakan', sedangkan yang kedua makna konotatif mengacu pada 'organ kelamin laki-laki'. Asosiasi pornografis yang dapat ditemukan berkaitan dengan konteks wacana data (8) memiliki acuan pada 'aktivitas seksual'. Hal itu ditandai oleh penggunaan kata kerja "dielus-elus" dan frase verba "bisa bikin".

Data (9)

Anak Mak Erot protes: Mak, kok beli mobil VISTO, kan pendek?

Mak Erot: Jangan takut, nanti mak uruuut jadi CARNIVAL.

Tampaknya penulis bahasa SMS sangat kreatif dalam memanfaatkan lingkungan di sekitarnya. Hal ini karena secara sepintas data (9) tidak mengandung makna konotatif apapun. Seperti diketahui bahwa nama diri yang digunakan, yaitu "Mak Erot" tidak memiliki 
makna apapun karena dari sekian ratus orang terdapat nama yang sama atau kembar. Akan tetapi, makna konotatif muncul justru pada kata ganti benda "Visto" dan "Carnival". Pemilihan kedua nama diri tersebut dimaksudkan untuk mewakili bentuk sebuah benda. Tentu saja benda yang memiliki elastisitas untuk diperbesar dari ukuran semula. "Visto" dan "Carnival" adalah merk mobil keluaran Korea yang diproduksi sama oleh KIA Motors Korea. Walaupun sama-sama diproduksi oleh satu industri otomotif, tetapi keduanya memiliki spesifikasi yang berbeda. "Visto" dirancang untuk memuat sedikit orang atau penumpang, sehingga bentuk mobilnya pun disesuaikan dengan kapasitas penumpang. Sebaliknya, "Carnival" memiliki bentuk yang relatiflapang sehingga mampu memuat banyak penumpang. Segi fisik yang membedakan kedua model mobil tersebut terletak pada ukuran besarkecil dan panjang-pendek.

Berdasarkan spesifikasi tersebut, makna yang dapat diketahui pada data (9) bahwa siapa nama diri yang ada pada data tersebut mulai terungkap. Pengungkapan tersebut lebih mudah dilakukan ketika ditemukan kata "urut". Jadi, berdasarkan analisis tersebut telah terjadi penyimpangan makna dengan menggunakan nama diri benda sebagai acuan guna mewakili benda lain. Benda lain yang dimaksud adalah 'organ kelamin laki-laki'. Hal ini dapat diketahui berdasarkan konteks sosial bahwa nama "Mak Erot" bukan nama yang asing dalam dunia lakilaki yang berurusan dengan masalah kejantanan. Metode pengobatan yang digunakan oleh Mak Erot adalah metode urut. Pengurutan dilakukan pada alat kelamin laki-laki dengan tujuan supaya alat vital tersebut menjadi bertambah besar dan panjang.

\section{G. Fungsi Pornografi dan Asosiasi Pornografis}

Disadari memang bahwa pemakaian kata-kata tertentu yang berasosiasi pornografi bukan semata-mata ditujukan untuk menunjukkan pornografis. Dalam hal ini, ada dua kemungkinan alasan yang patut dikemukakan, yaitu (i) adanya keterbatasan kosa kata, 
sementara itu ide atau konsep yang hendak disampaikan oleh penulis SMS kepada pembaca belum terwakili oleh kosa kata yang tersedia dalam bahasa Indonesia, dan (ii) unsur kesengajaan penulis SMS dengan maksud mengekspresikan ide yang sifatnya khusus, yang secara semantis diharapkan berbeda (mampu membedakan arti) dengan ekspresi verbal lainnya.

Pemakaian bentuk pornografis dan asosiasi pornografis merupakan hal yang disengaja oleh para penulis SMS untuk tujuan atau fungsi tertentu. Adapun tujuan atau fungsi yang diharapkan adalah untuk:

1. mempertegas makna

2. membuat sensasi

3. membuat keingintahuan

\section{Mempertegas Makna}

Untuk tujuan mempertegas makna, sekurang-kurangnya ada empat macam cara yang paling sering digunakan oleh penulis SMS, yaitu (i) memanfaatkan kosa kata yang tersedia yang secara konseptual atau denotatif bermakna pornografis, (ii) mempergunakan/ memanfaatkan bentuk metafora atau polisemi, (iii) memanfaatkan bentuk kolokasi, dan (iv) memanfaatkan bentuk perbandingan.

\section{a.Pemanfaatan Kata tertentu yang Bermakna Denotatif}

Selain menggunakan cara di atas, para penulis SMS mempergunakan satuan lingual tertentu yang telah tersedia dalam bahasa Indonesia. Satuan lingual itu secara konseptual atau secara denotatif bermakna pornografis. Ketegasan makna yang disampaikannya terlihat dari intensitas maknanya yang berbeda dengan makna umum. Contoh:

Data (10)

Di loby hotel seorang cowok menyentuh payudara cewek dengan sikunya.

Bila hatimu selembut susu, maafkan aku, kata si cowok. 
Si cewekmembalas, bila anumu sekeras sikumu, aku berada di kamar 69

Intensitas pemakaian makna dapat ditemukan pada data (10). Akan tetapi, penggunaan kata yang berbeda memiliki acuan sama. Kata tersebut yaitu "payudara" dan "susu". Penggunaan kedua kata tersebut menimbulkan makna asosiasi pornografis menjadi lebih tegas. Di samping itu, acuan terhadap kedua kata tersebut hanya berbeda pada masalah nilai rasa saja. Oleh karena itu, nilai rasa inilah yang dipengaruhi oleh intensitas serta acuan yang sama dalam menciptakan asosias pornografis data (10).

\section{b.Pemanfaatan Bentuk Metafora}

Upaya mempertegas makna di antaranya dapat ditempuh melalui pemakaian bentuk-bentuk metafora. Jadi, ada kekhasan makna yang hendak disampaikannya. Kekhasan itu tersirat dalam berbagai komponen makna. Komponen makna tersebut memiliki sifat khusus yang dapat dilihat pada fitur makna di komponen makna.

Data (11):

Kubuka bajubirumu, kuputar badanmu, kujilat tengahnya, kuisap susumu ouwh...takkuasa kubenamkan dan akhirnya, kurasakan betapa nikmatnya, makan OREO

Data (11) tampak menggunakan komponen makna yang terwujud dalam beberapa fitur. Komponen makna yang dimaksud untuk menunjukkan referensi "oreo". Komponen makna tersebut terdiri atas komponen warna yang ditandai kata "biru", komponen bentuk yang 
ditandai oleh kata "badan", "susu". Komponen tersebut membentuk suatu fitur benda yang memiliki karakteristik sama dengan oreo. Oreo adalah makanan ringan (kue kering) yang dijual di pasaran dengan fiturfitur seperti diperikan pada klausa maupun leksem data (11) di atas.

Penegasan makna yang dilakukan pada data (11) diketahui berdasarkan pada penggunaan komponen maupun fitur. Semakin banyak komponen yang digunakan, akan semakin membuat metafora tersebut semakin terinci. Hal demikian dilakukan tidak hanya terbatas pada komponen warna maupun bentuk seperti data (11), tetapi terdapat pula komponen yang menunjukkan sebuah aktivitas. Hal ini seperti terdapat pada data berikut.

Data (12)

Kau gerayangi tubuhku, Kau isap aku dengan mulutmu,

Kau mengeram di telingaku

Setelah puas, kau tinggalkan aku begitu saja

Dasarnyamuksialan!

Data (12) menunjukkan adanya komponen yang bersifat pada nonmanusia. Fitur yang digambarkan bukan pada bentuk melainkan pada sifat yang ditunjukkan secara spesifik pada aktivitas. Aktivitas tersebut ditunjukkan oleh kata "gerayangi", "isap", "mengeram". Rangkaian penggunaan kata-kata tersebut telah memiliki komponen makna yang mengacu pada tingkah nyamuk yang menghisap darah dari tubuh manusia. Akhirnya, komponen yang dijadikan acuan tidak hanya aspek bentuk saja, tetapi aspek lain, seperti aktivitas. Aktivitas tersebut diperikan dalam kata-kata yang mengandung penegasan sehingga menimbulkan asosiasi pornografis.

\section{c. Pemanfaatan Bentuk yang Berkolokasi}

Berbagai bentuk kolokasi dipergunakan pula untuk menciptakan asosiasi pornografis. Dalam hal ini, penulis SMS seringkali memadukan 
antara objek dengan perilaku atau sifat yang dimilikinya, seperti data berikut.

\section{Data(13)}

Makanan berprotein tinggi adalah

1 buah goreng SOSIS

ditambah 2 BAKSO dan SEJUMPUTRUMPUTLAUT

akan lebih nikmat jika ditambah SAUS PUTIH

yang dikocokterlebih dahulu

Data (13) memadukan perilaku dan sifat yang dimiliki sebuah objek dengan referen lain yang memiliki kesamaan sifat. Hal tersebut dapat diketahui pada kata "sosis". Kata tersebut mengambil referen alat kelamin laki-laki karena persamaan bentuk. Kemudian, kata "bakso" yang mewakili referen buah pelir. Kata "rumput laut" yang merepresentasikan rambut kemaluan, serta leksem atau kata "saus putih" yang mengacu pada cairan yang dihasilkan oleh alat kelamin laki-laki.

Penggunaan kata-kata tersebut dimaksudkan untuk menggambarkan atau menyamakan sifat serta karakteristik benda yang dijadikan acuan. Hal ini dilakukan karena beberapa alat atau organ manusia memiliki kesamaan baik bentuk maupun sifat dengan bendabenda yang berada di sekitar lingkungan manusia. Contohnya, kata "burung" yang hampir dipastikan memiliki acuan alat kelamin pria. Akan tetapi, persamaan sifat atau bentuk apakah yang ada sehingga kata tersebut hampir pasti mewakili organ pria tersebut.

\section{d.Pemanfaatan Simile}

Cara lain untuk mempertegas makna ialah dengan cara memanfaatkan bentuk perbandingan terutama bentuk simile, suatu bentuk perbandingan yang menunjukkan adanya sebagian kesamaan antarunsurnya.

Data (8).

Apa beda kucing dengan cowok, 
Kalo kucing dielus-elus tidur,

Kalo cowok dielus-elus bangun.

Apa beda daun pepaya dan tangan cewek,

Kalo daun pepaya bisa bikin daging jadi lembek,

Kalo tangan cewek bisa bikin daging menjadi keras.

Data (8) ditemukan penegasan makna yang dilakukan dengan melakukan perbandingan. Perbandingan yang dimaksud seperti tampak pada penggunaan kata "beda" dan "dengan". Lebih lanjut hal yang dibandingkan terdapat pada kata "kucing", "cowok", "daun pepaya", "tangan eewek". Kata-kata tersebut memiliki perbedaan yang ditegaskan dengan penggunaan kata "kalo". Penegasan tersebut dimaksudkan untuk menjelaskan maksud yang terkandung dalam data (8) tersebut. Maksud yang dituju tentu saja asosiasi pornografis melalui penggunaan maknă yang disimpangkan. Perbandingan pada tataran kalimat maupun kata pada data (8) secara semantik tidak menunjukkan adanya keterangan secara eksplisit. Namun, apa yang tersurat dalam data (8) tersebut telah menggiring pembaca SMS pada apa yang disebut makna asosiasi.

\section{Membuat Sensasi}

Untuk menciptakan sebuah sensasi penulis SMS seringkali melebih-lebihkan. Pengungkapannya sangat ekspresif sehingga terkesan di luar kewajaràn. Gaya bahasa yang dipergunakan merupakan gaya bahasa hiperbola. Untuk itu, untuk lebih memahami sensasi yang ada perlu memperbandingkan.

Data (14)

Kisah sukses, dalam setahun Warto dapat sekaligus

Mendirikan Wairteg, Wartel, dan Warnet.

Tapi Warti hanya butuh setengah menit

Dapat mendirikan Warto 
Gaya melebih-lebihkan pada data (14) dapat diketahui pada penggunaan kalimat pada baris pertama. Akan tetapi, maksud melebihkan tersebut ditujukan sebagai perbandingan terhadap hal yang lain. Dalam hal ini, yang menjadi pokok persoalan data (14) adalah kata "mendirikan". Perbandingan yang dilakukan meliputi hal-hal yang berkaitan dengan kata itu. Hal yang menjadi pebanding adalah warteg, wartel, dan warnet dan yang menjadi pembanding adalah warto.

Sensasi lain yang dapat diketahui pada data (14) yaitu penggunaan suku kata war- pada kata "warteg", "wartel", "warnet", "warto", dan "warti". Penggunaan fon atau bunyi yang memiliki kesamaan bukan tidak ada alasan. Akan tetapi, penggunaan tersebut dimaksudkan supaya apa yang menjadi tujuan penyampaian makna dapat terwujud dengan cara perbandingan. Hal inilah yang menimbulkan kesan adanya sensasi pada bunyi dalam mewujudkan asosiasi yang terjadi pada diri "warto" dan "warti" data (14) sebagai pelaku sekaligus penderita.

\section{Membuat Keingintahuan}

Suatu bentuk informasi ada kalanya tidak disampaikan secara utuh oleh penulis SMS. Oleh mereka, sebagian sengaja tidak ditampakkan.

\section{Data (15)}

Bila dikenakan dapat mengencangkan 2 benda, bila ditanggalkan dapat mengencangkan 1 benda.

Penasaran yang diungkapkan dalam hal informasi yang bersifat setengah-setengah juga terdapat pada data (15). Hanya saja, data (15) lebih mudah ditemukan informasi yang dimaksud. Dalam hal ini acuan yang dimaksud dengan segera dapat diketahui oleh pembaca SMS. Sekilas apa yang terkandung dalam data (15) tidak memiliki asosiasi apapun tentang hal-hal pornografi. Akan tetapi, penggunaan bilangan numeralia membantu pembaca SMS menemukan informasi yang 
tersembunyi.

Keingintahuan tersebut secara sengaja dilakukan untuk mencari apa asosiasi yang dimunculkan. Penggunaan numeralia seperti telah disebutkan kemudian dieksplisitkan lagi dengan kata "dikenakan" dan "ditanggalkan". Seolah-olah informasi yang dikandung kontradiktif. Tetapi, berawal dari hal itulah apa yang sebenarnya diinformasikan dapat tergali. Oleh karena itu, penggunaan kata-kata secara implisit lebih membutuhkan daya kreasi maupun imajinasi sehingga makna asosiasi dengan mudah dapat diketahui.

\section{Penutup}

Berdasarkan hasil analisis asosiasi pornografis dalam bahasa SMS pada bab-bab sebelumnya, simpulan pembahasan tersebut sebagai berikut.

Pertama, secara struktural data tersebut banyak memanfaatkan kalimat aktif dan kalimat sederhana. Memanfaatkan penghematan kata, memanfaatkan variasi struktur kalimat tunggal, memanfaatkan kata, dan memanfaatkan frase. Secara semantik, data yang bernuansa pornografis didominasi oleh dua kemungkinan pola, yaitu (i) berpola pelaku tindakan penderita, jika berstruktur klausa aktif, dan (ii) berpola penderita tindakan jika berstruktur klausa pasif. Dua kemungkinan itu berlaku bagi suatu klausa dalam struktur yang wajar, tanpa inovasi.

Kedua, untuk menyampaikan ide dengan nuansa pornografis di dalamnya, para penulis SMS menggunakan teknik-teknik tertentu. Teknik yang paling sederhana ialah memanfaatkan kosa kata tertentu yang secara konseptual bermakna pornografi. Hal ini terutama dimaksudkan untuk memunculkan makna pornografi. Teknik lainnya ialah pemanfatan bentuk metafora, pemanfaatan satuan lingual tertentu yang bermakna asosiasi pornografis. Selain itu, penggunaan polisemi dalam bentuk bahasa figuratif merupakan cara yang paling umum dilakukan oleh penulis SMS guna menimbulkan asosiasi pornografis pembaca.

DIKSI Vol.11, No.2, Juli 2004 
Ketiga, nuansa pornografi banyak bersinggungan dengan persoalan perilaku atau aktivitas dan objek benda. Oleh karena itu, referensi pornografi dan asosiasi pornografis banyak mengacu pada perilaku atau aktivitas dan benda (objek).

Keempat, pemakaian bentuk pornografi dan asosiasi pornografis merupakan hal yang disengaja oleh para penulis SMS untuk tujuan tertentu. Berbagai tujuan yang diharapkannya adalah untuk mempertegas makna, membuat sensasi, dan membuat keingintahuan pembaca SMS.

\section{DAFTAR PUSTAKA}

Aminuddin. 1988. Semantik: Pengantar Studi tentang Makna. Bandung: Sinar Baru

Chaer, Abdul. 1990. Pengantar Semantik Bahasa Indonesia. Jakarta: Rineka Cipta . 1994. Linguistik Umum. Jakarta: Rineka Cipta

Dirven, Rene. 1985. "Metaphor for Extending The Lexicon" dalam Wolf Paprotte dan Rene Dirven. The Ubiquity of Metaphor. Amsterdam: John Benjamin Publishing Company

Djajasudarma, Fatimah. 1993. Semantik 1: Pengantar ke Arah Ilmu Makna. Bandung: Eresco . 1993. Semantik 2: Pemahaman Ilmu Makna. Bandung: Eresco

Halliday, M.A.K.1985. An Introduction to Functional Grammar. Bedford Square London: Edward Arnold

Keraf, Gorys. 1991. Diksi dan Gaya Bahasa. Jakarta: Gramedia

Koentjaraningrat. 1979. Pengantar Ilmu Antropologi. Jakarta: Aksara Baru

Leech, Geoffrey. 1997. Semantics. Diterjemahkan oleh Drs. Paina dan Soemitro S.H. Surakarta: Sebelas Maret University Press

Lesmana, Tjipta. 1995. Pornografi dalam Media Massa. Jakarta: Puspa Swara 
Nida, Eugene A.1986. Componential Analysis of Meaning. Paris: Mouten The Hague

Nusarini. 1998. Homonimi dalam Bahasa Indonesia. Yogyakarta: Tesis UGM

Sudaryanto. 1988. Metode Linguistik Bagian Pertama: ke Arah Memahami Metode Linguistik. Yogyakarta: Gadjah Mada University Press

Tarigan, Henry Guntur. 1985. Pengajaran Semantik. Bandung: Angkasa

Ullman, Stephen.1972. Semantics An Introduction to The Science of Meaning. Oxford: Basil Black Well

Wijana, I Dewa Putu. 1995. Wacana Kartun dalam Bahasa Indonesia. Disertasi Pascasarjana UGM

. 1995. "Bahasa Indonesia dalam Cerita Humor" Kumpulan makalah MLI II Denpasar, Bali

1999. Semantik. Yogyakarta: Fakultas Sastra Universitas Gadjah Mada 2003. "Pornografi dan Asosiasi Pornografis pada Judul Rubrik Artis Harian Bernas". Yogyakarta. Makalah Fakultas Ilmu Budaya UGM 